\title{
Development Of Teacher Handbooks And Realistic Mathematics Students Basic Schools
}

\author{
Dian Armanto', Edy Surya ${ }^{2}$, Elvi Mailani $^{3}$ \\ Faculty of Mathematics and Natural Science, Universitas Negeri Medan, Indonesia ${ }^{1,2}$ \\ Faculty of Education, Univeristas Negeri Medan, Indonesia ${ }^{3}$ \\ armanto_dian@yahoo.com
}

\begin{abstract}
The research aims to develop teacher and student handbooks for realistic mathematics lessons for elementary schools. This research uses development research. The subjects of this study were grade V students of SD Negeri 163085, H.A Bilal Tebingtinggi City and SD Negeri 106162, Medan Estate District, Deliserdang Regency. In the initial stage, observations were made during the learning process at the two schools and continued with interviews with students and teachers. From the results of these observations and interviews a primary school realistic mathematics teacher and student handbook was prepared. Furthermore, the realistic elementary school mathematics teacher and student handbook is validated by a team that aims to see and assess the quality of the realistic elementary school teacher and student mathematics handbook in order to arrange an effective handbook that will be used by teachers and students in learning. The trial results show that the elementary school teacher and student mathematics handbook is effective and can help facilitate understanding of mathematical concepts at the elementary school level. This can be seen from the number of students who can reach the KKM from the two schools is increasing. For SD Negeri 163085 HA Bilal, Tebingtinggi City, if at the time of the pre-test only 1 student (3\%) was able to reach the KKM, then after being given the learning process using a teacher and student handbook developed the number of students who could reach the KKM increased to 24 students $(82.7 \%)$ while those under the KKM were only $(17.3 \%)$ or 5 students. The same thing was seen in SD Negeri 106162. If at the time of the Pre-test only 2 students $(6.6 \%)$ had scored above the KKM, after the post-test there was an increase in students who achieved the KKM score of 25 students $(83.3 \%)$. An increase of $76.7 \%$ when compared to the pre test.
\end{abstract}

Keywords: Handbook, teacher, student, PMR

\section{Introduction}

In the 2013 curriculum, subjects must be attended by all students in one education unit at each unit or level of education. While for the elective subjects participated by students, chosen according to their choice. Based on Permendikbud no 24 of 2016 it was emphasized that the implementation of learning in Elementary Schools / Madrasah Ibtidaiyah (SD / MI) was carried out with a thematic-integrated learning approach. According to Sri Muryaningsih [1] that 
"thematic learning is learning that utilizes themes in the delivery of material. The theme acts as a unifying learning activity that brings together several subjects at the same time by choosing a theme that can unite indicators of several elementary school subjects. Elementary school subjects that can be taught using thematic learning are: Religious Education, Civic Education (PKn), Indonesian Language Education (BI), Mathematics, Natural Sciences (IPA), Social Sciences (IPS), Cultural Arts and Crafts (SBDP) ), and Physical Education Sport and Health (PJOK) ". However, for Mathematics and Physical Education Sports and Health (PJOK) subjects as stand-alone subjects for classes IV, V, and VI.

According to the Ngurah Laba Laksana Dek [2] "in the 2013 curriculum framework it also states that in compiling and developing learning activities must pay attention to the principles of preparation and development in accordance with the conditions in the education unit both the initial ability of students, interests, motivation to learn, talent , potential, social abilities, emotions, learning styles, special needs, learning speed, cultural background, norms, values, and / or the environment of students ".

According to Hengkang Bara [3] "it is known that there are still some obstacles encountered in the preparation and implementation of the 2013 Curriculum. There is still a lack of understanding of teachers in implementing the new curriculum in classroom learning. This is because the training and outreach time are considered too short. The number of learning resources that will be changed and replaced with new learning resources. In addition, the distribution of teaching materials is not optimal and has not been evenly distributed to all schools designated by the government to implement the 2013 curriculum. Therefore, teachers as educators are required to be able to respond to the transition period of curriculum changes by innovating through the development of creativity in learning. One of the things teachers can do is to develop learning media that are effective, interesting, in accordance with the characteristics of students ".

But in reality, based on the results of observations and observations in the field, most primary schools do not use teacher books and student books that are separate and independent of the binding theme. This situation was also seen in the two schools that were sampled in this research activity. SD Negeri 163085 Jalan H.A Bilal Tebingtinggi in the process of learning mathematics in class V, teachers and students still use mathematics books that are still integrated in themes with other subjects. When interviewed with students, students said it was difficult to understand various mathematical concepts because the explanations contained in the books they used were very few and not exhaustive. The same thing was also said by the teacher, because sometimes the teacher himself felt confused and overwhelmed when he had to explain certain concepts because their mastery of material concepts was still lacking and the handbook used to explain the concept of the material was very concise.

A similar situation was also found in SD Negeri 106162, Medan Estate District, Deliserdang Regency. Teachers and students feel the book they are using today does not provide much support for understanding the concept of material because of its very short description. Such conditions certainly cannot be tolerated and a solution must be immediately sought. The development of a handbook for elementary school students and realistic mathematics teachers is felt to be needed to assist teachers and students in providing easy understanding of the mathematics material being studied.

According to Hamdan Batubara [4] "understanding mathematical concepts and communication is a competency that must be developed in students so that they are ready to face 
life's problems in the future. In addition, affective competence, such as the spirit of learning, independence and perseverance is also an important asset for students in developing their potential to the fullest ".

According to Rusnandi [5] states that "learning mathematics is a process of building or constructing concepts and principles, not just teaching that seems passive and static, but learning must be active and dynamic". So, learning mathematics in addition to requiring concepts, teachers also need media that can help in an active and dynamic learning process. Teachers can develop simple media, for example by developing teacher handbooks.

"The role of books is very large because books can act as a source of information, but currently students also have a tendency to lack interest in reading if the book is thick and less attractive" [6]. Teacher handbooks are books that are used by teachers as a source of reference in implementing the learning process for their students $[7,8]$. There are three ways teachers can use in compiling handbooks, namely repackaging information, writing themselves, and restructuring. Teacher handbooks can also come from research results. Efforts that can be made to create a research-based teacher handbook is the way the writer must first conduct research and report the results of his research.

Generally teacher handbooks have several characteristics or characteristics such as: (1) using a systematic structure and sequence of contents, (2) explaining the instructional goals to be achieved, (3) motivating students to learn, (4) anticipating student learning difficulties, (5) ) provide sufficient training for students, (6) provide summaries, (7) teaching materials are independent [7]. The existence of basic competencies (KD) and learning objectives that must be achieved by students, has forced teachers to develop teacher handbooks in accordance with this [8]. Teacher handbooks will be more meaningful if the material contains contextual content and is in the daily environment of students [9].

The student handbook is used as a guide to learning activities to facilitate students in mastering certain competencies. This book is also used to carry out activities in the learning process (activities based learning) where the contents are designed and supplemented with examples of activity sheets so that students can learn something relevant to the life they experience. The student handbook has the function: (a) A guide for students in carrying out learning activities, (b) Liaison between teachers, schools and parents, (c) student worksheets, (d) Assessments and portfolios, and (e) Communication media between teacher and students.

In learning realistic mathematics, students learn to mathematize contextual problems. In other words, students identify that contextual questions must be transferred into mathematical form problems to be further understood, through scheming, formulation and visualization. This is a horizontal mathematical process. While vertical mathematical, students complete mathematical forms of contextual questions by using mathematical concepts, operations and procedures that are applicable and understood by students [10].

According to Freudenthal [11], the main activities carried out in Realistic Mathematics Education include: finding contextual problems (looking for problems), solving problems (solving problems), and organizing teaching materials (organizing a subject matter ).

According to Maghfirah Maharani [12] "In order for mathematics learning to be well conveyed and accepted by students, it requires the latest innovations in learning mathematics, namely by utilizing learning media in order to arouse students' desire to learn mathematics and reduce student anxiety in learning mathematics". So, one alternative is to use realistic mathematics 
teaching material. It is expected that the learning process in class can be carried out well and accepted by students.

\section{Research Method}

The development of realistic elementary school mathematics teacher and student handbooks uses the development research method Richey and Nelson. Development research (Developmental research) is oriented towards product development in which the development process is described as thoroughly as possible and the final product is evaluated. Van den Akker [13] calls it formative research where his research activities are carried out in a cyclic process and are aimed at optimizing the quality of product implementation in certain situations. In mathematics learning, this developmental research is applied in the iterative activities of designing and testing mathematics learning material products [13]. The results of this study are quality products theoretically, procedural methodologies, and empirical.

Researchers used six elements contained in the Van Den Akker development model, namely: (1) Preliminary Analysis, (2) Evaluation of experts and teachers, (3) initial book models, (4) book validation (5) empirical data, (6) reflection and revision. The sequence of development steps The diagnostic test book based on the Van Den Akker research and development model can be seen from the following figure:

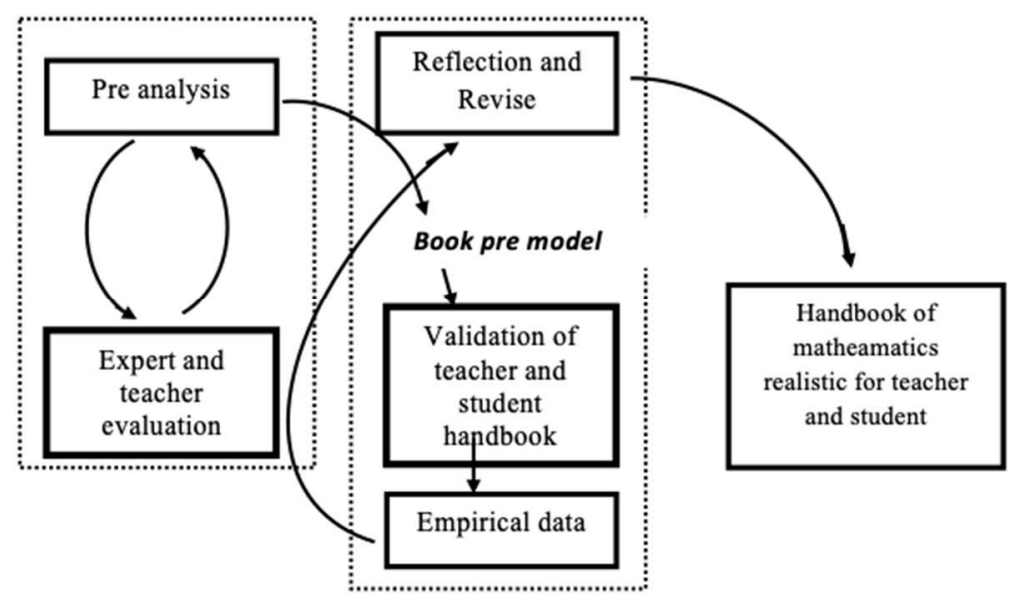

Fig 1. Diagram of the research and development model of Van den Akker (1999)

\section{Trial of elementary school teacher and student mathematics handbook}

The trial of elementary school teacher and student mathematics handbook aims to see the use of elementary school teacher and student mathematics handbook in the teaching and learning process. Besides this trial also aims to see the constraints and weaknesses of teacher and student 
handbooks developed in the school environment. The elementary school teacher and student mathematics handbook trials were conducted at two schools that were sampled in this teacher and student development activities. The results of this trial will be input and consideration in developing elementary and realistic mathematics teacher and student handbooks.

\section{Reflection and revision}

Reflection and revision of the realistic elementary school teacher and student handbooks aims to see the weaknesses and shortcomings of the teacher and student handbooks based on trials that have been conducted at two sample schools. Weaknesses and shortcomings of the draft based on the results of the trial will be corrected to produce good quality teacher and student handbooks.

\section{Validation}

The second elementary and realistic mathematics teacher handbook validation was carried out after all the tools developed were tested, reflected and revised by the researcher. Validation activities are intended to produce elementary and realistic mathematics teacher and student handbooks that are effective and can improve the competency of elementary school students. Validation is done using a validation sheet that has been prepared previously. Validation was carried out by one expert and 3 teachers who were competent in the fields of mathematics, education, and learning media.

\section{Development of elementary and realistic mathematics teacher and student handbooks}

The development of elementary school teachers and students 'realistic mathematics handbooks was carried out after the validation of elementary school teachers and students' realistic mathematics handbooks was conducted. Elementary teacher and student mathematics handbooks that were developed later will be used in elementary schools as a teacher and students' grade handbook especially in mathematics. This is because the mathematics book that has been used for fifth grade elementary school students still uses a thematic approach, while the candy demand for 24 of 2016 that mathematics is already independent.

\section{Results and Discussion}

This realistic elementary school teacher and student mathematics handbook is validated by a team of validators consisting of experts and experts from the tertiary level and educators at the elementary level. Validation is done using a predetermined validation sheet. Based on the results of the validation team, the teacher's handbook and realistic elementary school mathematics students are included in the good category and deserve to be tested and developed.

The realistic elementary school teacher and student handbook trial was conducted in two elementary schools in Tebingtinggi City and Deliserdang Regency. SD Negeri 163085 Tebingtinggi City, North Sumatra Province is the first school as a testing ground, while SD Negeri 106162 Medan Estate District Deliserdang Regency is the second school. The trial was conducted on the fifth grade students of odd semester 2019/2020 learning year. The average age of students 
who are subjected to trials in the development of this elementary and realistic mathematics student handbook is 10-11 Years. The number of grade V students of SD Negeri 163085 Tebingtinggi City who were the subjects of this trial were 29 participants, while the number of grade V students of SD Negeri 106162, Medan Estate Subdistrict, Deliserdang Regency, were 30 students. The trial was conducted in two stages, namely the pre test and post test stages. The implementation of pretest and post-test in the activities of developing elementary and realistic mathematics teacher's handbook can be seen in the following table:

Table 1. Timing of the pilot development of the teacher and student handbook elementary realistic mathematics

\begin{tabular}{clcc}
\hline \multirow{2}{*}{ No } & \multirow{2}{*}{ School } & \multicolumn{2}{c}{ Trial } \\
\cline { 3 - 4 } & & Pre Test & Post Test \\
\hline 1 & SD Negeri 163085 & 16 July 2019 & 20 August 2019 \\
2 & SD Negeri 106162 & 15 July 2019 & 21 August 2019 \\
\hline
\end{tabular}

The results of the pre-test conducted in the two schools that became the study sample, showed that the ability of Grade V students of SD Negeri 163085 Tebingtinggi City and SD 106162 in Deliserdang Regency in answering questions related to fraction material was still very low. This can be seen from the percentage of classical completeness obtained at the two elementary schools is still far from the KKM that has been determined. Of the twenty questions given to students to work on average only\% of students can answer in accordance with the KKM that has been determined, while the remaining\% is still not fulfilling the KKM that has been determined. The description of the pre-test results of the two schools that were sampled in this research activity, as in the following graph:

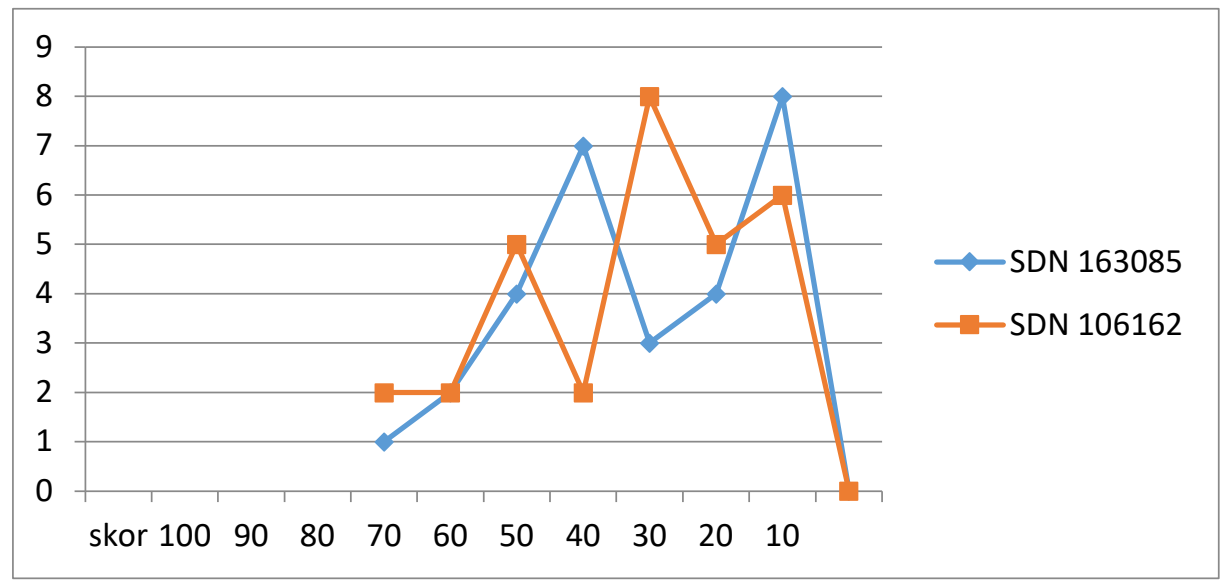

Fig 2. Student Pre Test Result Graph 
Based on the graph above, it can be seen the number of students who can work on questions and get grades above the KKM from SD Negeri 163085 Tebingtinggi City, only as many as 1 student $(3 \%)$ while as many as 28 students $(97 \%)$ pre-test results are still below the KKM which predetermined. The same thing can also be seen from the results of the pre-test conducted in 106162 SD Negeri Medan Deliserdang District, out of 30 students in class V who were sampled in the trial, only 2 students $(6.6 \%)$ who scored above the KKM has been determined, the rest as many as 28 students $(93.4 \%)$ have grades below the KKM.

Seeing the results of the trials conducted in the pre-test activities, it is believed that one of the causes of the low ability of students to work on problems related to fractions contained in the 2013 curriculum learning is because learning books are one of the sources of reference and learning materials for students. not in accordance with the demands of the material that must be mastered by students. Mathematics books that are used still use books that use a theme approach, while for grade IV to VI students, based on the Ministry of Education and Culture regulation, it is stated that mathematics is independent and is not included in the theme. Mathematics books that are still joining the theme, certainly do not help students in understanding abstract mathematical material, because the discussion of concepts contained in books based on themes is still very narrow and very limited.

Elementary teachers and students' realistic mathematics handbooks are felt to be very much needed by students. Based on this statement, a realistic elementary school mathematics teacher and student handbook was developed. The use of teacher's handbooks and student books, is expected to help teachers in providing understanding of the concepts of mathematical material, and for students themselves with this book is expected to easily understand the material and learning outcomes of mathematics can be much more improved.

Furthermore, for grade V students of SD Negeri 163085 Jalan H.A Bilal Tebingtinggi City and SD Negeri 106162 Medanestate Deliserdang Regency, action was given in the form of learning processes using student handbooks and realistic elementary mathematics teacher handbooks developed by researchers. The learning process using the teacher's handbook and realistic elementary student mathematics handbook is held a month and at the end of the activity a post-test is carried out with the aim to see how far the improvement of students' abilities after the learning process is carried out using the teacher's handbook and student handbook developed by researchers.

The results of the post-test conducted at the end of the activity showed an increase in the ability of students in terms of understanding mathematics material in class V. This can be seen from the number of students who can reach the KKM from the two schools is increasing. For SD Negeri 163085 HA Bilal, Tebingtinggi City, if at the time of the pre-test only 1 student (3\%) was able to reach the KKM, then after being given the learning process using a teacher and student handbook developed the number of students who could reach the KKM increased to 24 students $(82.7 \%)$ while those under the KKM were only $(17.3 \%)$ or 5 students. The same thing was seen in SD Negeri 106162, Medan Estate District, Deliserdang Regency. If at the time of the Pre-test only 2 students $(6.6 \%)$ had scored above the KKM, after the post-test there was an increase in students who achieved the KKM score of 25 students $(83.3 \%)$. An increase of $76.7 \%$ when compared to the pre test. Likewise with students who scored below the KKM in both elementary schools there was a significant decrease. The description of the increase in the ability of fifth grade students after 
using the teacher's handbook and realistic elementary student mathematics handbook can be seen in the following graph:

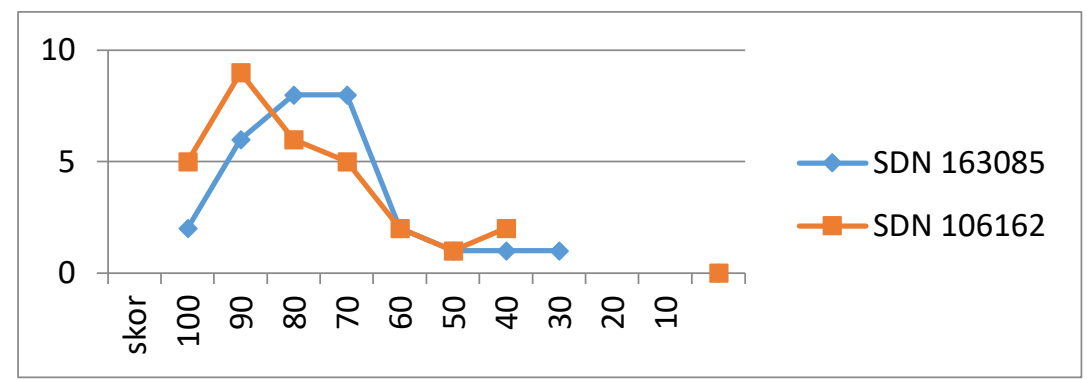

Fig 3. Student Post Test Result Graph

Based on the graph above, it appears that an increase in the ability and understanding of grade V students of SD Negeri 163085 Jalan H.A Bilal Tebingtinggi City and SD Negeri 106162 Medanestate Subdistrict Deliserdang District after the learning process was carried out using a teacher's handbook and realistic elementary mathematics students. The improvement of students' abilities in the two elementary schools can be seen in the following table:

Table 2. Results of improving students' abilities

\begin{tabular}{cccccc}
\hline \multirow{2}{*}{ No } & \multirow{2}{*}{ School } & \multicolumn{2}{c}{ Pre Test } & \multicolumn{2}{c}{ Post Test } \\
\cline { 3 - 6 } & & $\begin{array}{c}\text { Above } \\
\text { KKM }\end{array}$ & Under KKM & $\begin{array}{c}\text { Above } \\
\text { KKM }\end{array}$ & Under KKM \\
\hline 1 & SD Negeri 163085 & $3 \%$ & $97 \%$ & $83 \%$ & $17 \%$ \\
2 & SD Negeri 106162 & $7 \%$ & $93 \%$ & $83 \%$ & $17 \%$ \\
\hline
\end{tabular}

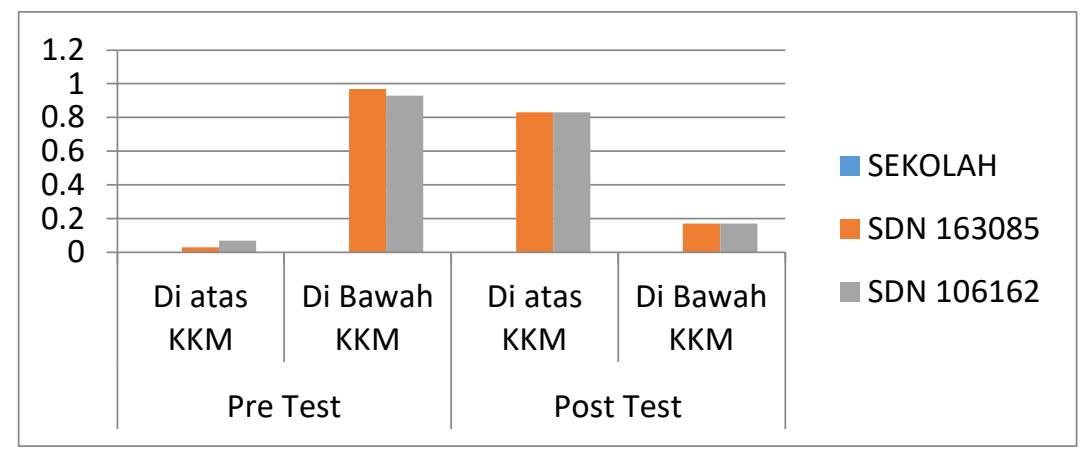

Fig 4. Results of improving student ability 


\section{Conclusion And Suggestions}

\section{Conclusion}

1) The development of realistic elementary school mathematics teacher and student handbooks, very useful for teachers and in particular improving students' understanding of elementary school level mathematics material.

2) Increasing students' understanding of elementary school mathematics material can be seen from the results of trials conducted at the two schools that were sampled in the activities of developing elementary school teacher and student realistic mathematics handbooks.

3) V grade students in elementary school feel very happy and are helped by the existence of this handbook because they are easier to understand various mathematical material and can explore the material independently.

\section{Suggestions}

1) Need to develop realistic elementary school teacher and student mathematics handbooks in other classes

2) The elementary school teacher and student mathematics handbook development test was conducted by more than two schools in order to get a better and more accurate picture and validity from the handbook developed.

\section{References}

[1] Sri Muryaningsih, A. M. Pengembangan RPP Tematik-Integratif untuk Meningkatkan Karakter Kerja Keras di Sekolah Dasar. Jurnal Prima Edukasia, 190-201. (2015).

[2] Dek Ngurah Laba Laksana, I. G. Pengembangan Multimedia Pembelajaran Tematiksekolah Dasar Berbasis Budaya Lokal Masyarakat Flores. Jurnal Pendidikan Dasar Nusantara, 151-162. (2017).

[3] Hengkang Bara Saputro, S. Pengembangan Media Komik Berbasis Pendidikan Karakter Pada Pembelajaran Tematik-Integratif Kelas IV SD. Jurnal Edukasia, 61-72. (2015).

[4] Batubara, H. H. Pengembangan Media Pembelajaran Matematika berbasis Android untuk Siswa SD/MI. Muallimuna, 12-27. (2017).

[5] Enang Rusnandi, H. S. (n.d.). Implementasi Augmented Reality (AR) pada PengembanganMedia Pembelajaran Pemodelan Bangun Ruang 3D untuk Siswa Sekolah Dasar. Infotech Journal, 24-31.

[6] Ardian Asyhari, H. S. Pengembangan Media Pembelajaran Berupa Buletin dalam bentuk Buku Saku untuk Pembelajaran IPA Terpadu. Jurnal Ilmiah Pendidikan Fisika Al-BiRuNi , 1-13. (2016). 
[7] Suhardjono. Menyusun Buku Ajar. Pelatihan Penulisan Buku Ajar Program Studi Magister Pendidikan Guru Madrasah Ibtidaiyah PPS Universitas Islam Negeri Maulana Malik Ibrahim Malang, Sabtu 4 juni 2011. (2012).

[8] Ngadimun, DH. Penyususnan Buku Ajar. Bandar lampung: Disampaikan pada Pelatihan Penyususnan Buku Ajar bagi Dosen FISIP Unila. (2013).

[9] Parmin, EP. Pengembangan Modul Mata Kuliah Strategi Belajar Mengajar IPA Berbasis Hasil Penelitian Pembelajaran. (2012).

[10] Armanto, Dian. "Alur Pembelajaran Perkalian dan Pembagian Dua Angka dalam Pendidikan Matematika Realistik (PMR)". Disajikan pada Seminar Nasional Pendidikan Matematika Realistik di Universitas Sanata Dharma Yogyakarta tanggal 14- 15 November 2001. (2001).

[11] Fauzan, Ahmad. "Pendidikan Matematika Realistik: Suatu Tantangan dan Harapan.", disajikan pada Seminar Nasional Pendidikan Matematika Realistik di Universitas Sanata Dharma Yogyakarta tanggal 14- 15 November 2001. (2001).

[12] Maghfira Maharani, N. S. Media Pembelajaran Matematika Berbasis Kartun untuk Menurunkan Kecemasan Siswa. Jurnal Matematika, 101-106. (2018).

[13] Van den Akker, Jan. Principles and methods of development research. In Jan van den Akker et al. (Ed.) Design Approaches and Tools in Education and Training pp. 1-14. Dordrecht: kluwer Academic Publishers. (1999).

[14] Agustyaningrum, N., \& Yusnita, Y. Pengembangan Bahan Ajar Struktur Aljabar Berbasis Pendekatan Deduktif Untuk Meningkatkan Hot Skill Mahasiswa Universitas Riau Kepulauan (Unrika) Batam. Jurnal Dimensi, 6(2). (2017). 